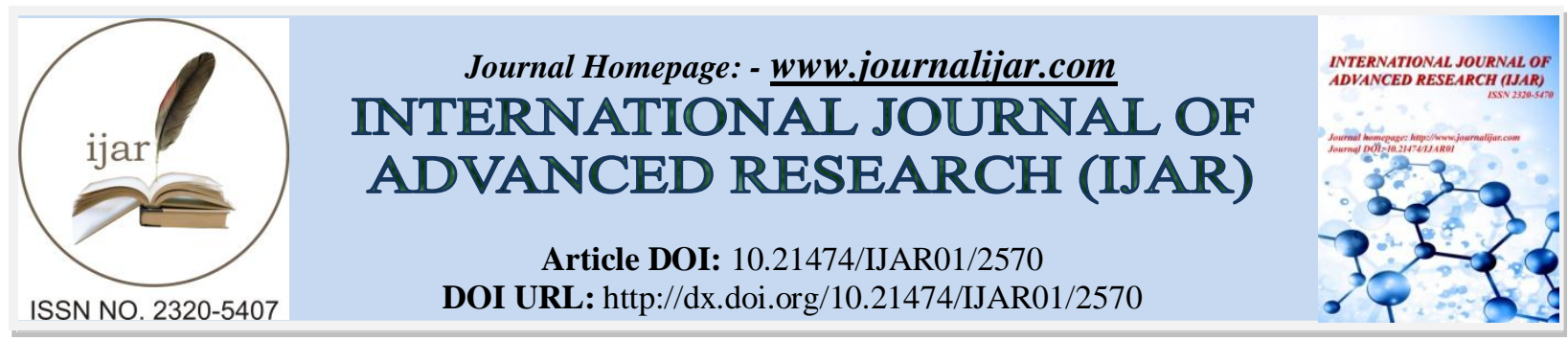

RESEARCH ARTICLE

\title{
FLOOD HAZARD ZONATION AND VULNERABILITY ASSESSMENT OF GREATER SRINAGAR, J\&K INDIA.
}

Hakim Farooq Ahmad, M.Sultan Bhat, Akhtar Alam and Shabir Ahmad. Department of Geography and Regional Development University of Kashmir-190006.

\section{Manuscript Info}

\section{Manuscript History}

Received: 27 October 2016

Final Accepted: 25 November 2016

Published: December 2016

Key words:-

GIS, flood, vulnerability Mapping, composite index, multi-criteria analysis.

\section{Abstract}

The present study addresses the importance for a vibrant and cost effective methodology for the making of flood vulnerability and hazard maps particularly for those areas which are frequently affected by floods and pose a recurrent danger. Taking the case of Greater Srinagar, Jammu and Kashmir and using the historical database for a number of the variables, obtained from different government agencies, the study came up with the detailed hazard and vulnerability maps of the study area, indicating different levels of the hazard and exposure with respect to people and assets, which can be used for further detailed investigating and planning. Flood vulnerability assessment is pivotal for devising an effective flood management plan. In order to assess the vulnerability of Greater Srinagar to floods, weighted overlay analysis in GIS environment has been performed using selected (sensitive to flood vulnerability) physical and socioeconomic indicators As the city includes both urban and rural areas, the spatial analysis unit was taken as ward and village for urban and rural areas respectively. The indicators were reclassified to a common evaluation scale (1-5) for analysis. Since the indicators contribute differently to flood vulnerability therefore based on their sensitivity, a percent (\%) influence value was assigned to each indicators. Based on the analysis three flood vulnerability classes of Greater Srinagar were identified i.e. Highly Vulnerable, Moderately Vulnerable and Least Vulnerable.

\section{Introduction:-}

The frequency of floods worldwide has increased manifold, on an annual basis floods put down over 3 million people homeless and affect the individual and economic fortunes of another 60 million people (world commission on Disasters, 2000). The frequency of natural disasters has been increasing over the years, resulting in loss of life, damage to property and destruction of the environment. The occurrence is found frequently even in developed countries like USA, UK, Australia, and New Zealand and so on at varied proportion. Some 5 million Chinese lost their lives in floods between 1860 and 1960 (Ghosh, 2006). Vulnerability is dynamic; changes over space and through time (Cutter and Finch 2008). It has emerged as a central concept for understanding what it is about the condition of people that enables a hazard to become a disaster, however, almost every aspect of vulnerability conceptualisation and measurement is the subject of intense debate (Tapsell et al. 2010). We are still dealing with a 
paradox: we aim to measure vulnerability, yet we cannot define it precisely (Birkmann 2006). Although vulnerability is an intuitively simple notion, it is surprisingly complex to define and even more difficult to quantify and apply in practice (UNEP 2002). In spite of the conceptual discussion and the difficulty to define and construct appropriate indicators to map vulnerability, the identification and monitoring of places with a certain degree of vulnerability remains still a challenge considering the multifaceted nature of the vulnerability (Kienberger 2007).

Social vulnerability is not unswervingly clear phenomenon and there are some problems in quantification. Many researchers have paid much more attention on the theoretical and conceptual aspects of social vulnerability (Turner et al., 2003; Adger, 2006; Barroca et. al. 2006), yet relatively few have presented methods to measure it empirically. One of the most common approaches for characterizing social vulnerability is the use of a range of indicators (Cutter et al., 2003; Birkmann 2006; Burton and Cutter, 2008, Eakin and Luers 2006). In essence, social vulnerability can be interpreted as inherent inequality with respect to natural hazards. There are several methods for flood mapping based primarily on hydrologic, meteorological and geomorphologic approaches. Particularly, in developing countries where hydro meteorological data are commonly insufficient and inaccurate and restricted to generate flood models, the geomorphologic method demonstrated its effectiveness and appropriateness (Wolman, 1971; Cancado et al., 2008) because this method applies aerial photos interpretation and field investigation of flood evidences to study geomorphologic characteristics in relationship with social indicators and historical flood events (Fekete et al., 2009; Goodyear et. al. 2011).

The river Jhelum which is the main drainage basin is prone to recurrent floods which inundates the whole Kashmir valley floor including Srinagar as well. Flooding has been a recurrent phenomenon in Srinagar which causes great loss to life and property as well. The major causes of flood hazard in the area are the torrential rainfall and heavy melting of snow, ice and glaciers in the upper catchment area. Besides there are some intensifying factors such as the heavy encroachment over the low lying area and over the flood plan of river Jhelum which is the effect of increased urbanization, that means a huge number of population is exposed to floods that is during summer season the discharge increases and in effect the excess water overflows the natural level and causes great damages to life and property of the area, the more increased urbanization has exposed more human population and assets to floods which directly increases the flood-risk vulnerability (Koul 1978)

The physiographic make up of the major part of the study area had made it vulnerable to varying degrees of flood hazards and water logging problems. The urban expansion has taken place in the marginal areas of the greater city which has low laying physiography as it constitutes the part of the Jhelum valley floor.(Koul 1991, Bhat and Alam 2014)

The present study will be of significant importance as its focus has been the identification of the areas of greater Srinagar vulnerable to different types of flood risks, which will be utilized as a vital input for the formulation of planning strategies with regard to flood control and management policies. The study would also be helpful in the formulation of the urban growth policies of Srinagar, particularly in demarcating the areas favourable for physical expansion of the city.

\section{Study Area:-}

Srinagar, the largest among all the Himalayan urban centres is located in the heart of Kashmir valley. The Greater Srinagar is located between the coordinates $33^{\circ} 53^{\prime} 49^{\prime \prime} \mathrm{N}-34^{\circ} 17^{\prime} 14^{\prime \prime} \mathrm{N}$ and $74^{\circ} 36^{\prime} 16^{\prime \prime} \mathrm{E}-75^{\circ} 01^{\prime} 26^{\prime \prime} \mathrm{E}$. It is situated at an altitude of 5200 feet above mean sea level and spreads over in the midst of an oval shaped valley of Kashmir (Fig.1, study area shown) It is encircled by the natural wall of mountains (the sub mountain branches of the Pir Panjal Range) whose height varies from 1800 to 4300 meters above mean sea level (Koul 1993) The Greater Srinagar covers an area of $1068.70 \mathrm{~km}^{2}$ with a population of 1624 persons. The area is mostly spread across the Jhelum valley floor characterized by gentle undulating topography, while the south-west and southern peripheries have presence of elevated lands known as kerawas, which occupy large areas in the Tehsils of Budgam, Chadura, Pampore and Pulwama. The area suitable for development in the north is limited to the north-west and the south while the eastern extension is limited to the present municipal limits, as the physical extension of the settlements in this area is hindered by Zabarwan hills (Raza et. al 1978) 


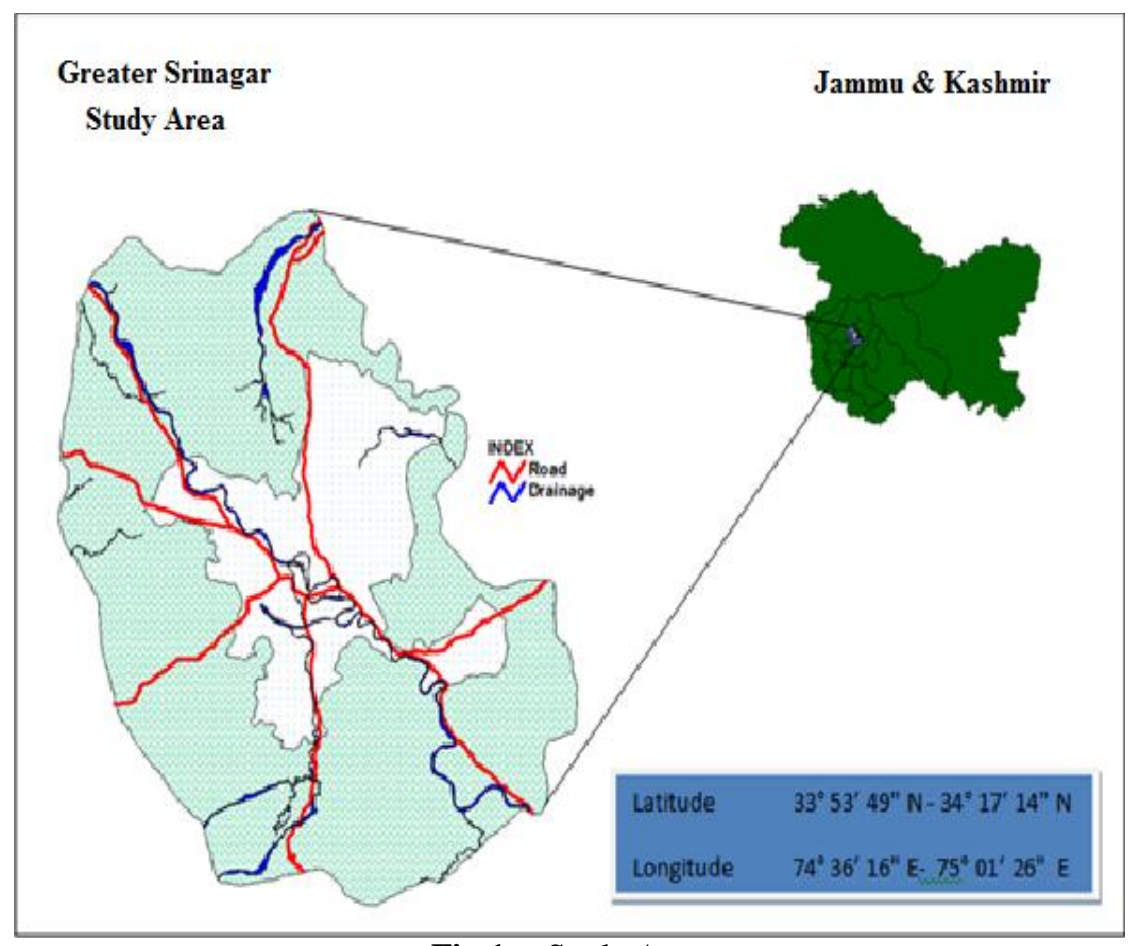

Fig 1:- Study Area

In terms of physical characteristics, Srinagar is situated along the perennial river Jhelum, which has helped greatly in the formation of a modal place of the oval shaped valley and also added significance to function as an apex urban centre of the region. Srinagar is the Primate City in the region because its population is disproportionately larger than other towns of the valley. On socio-economic front; it acts as the nerve centre of the valley. Since historic times, it has been the seat of government as well as the centre of religious and cultural activities for about 1400 years. It attracts a large number of populations outside the municipal limit on different religious occasions (Bhat, M.S 2008). Functionally it is the growth potential centre from the fact that it constitutes a comparatively highest percentage of population in secondary and tertiary sectors when analyzed in comparison with the other towns of the valley.

\section{Data Sets and Methodology:-}

One of the important tasks under this research was to assess the flood vulnerability of the places and people of Greater Srinagar. Though a number of studies have been conducted to assess the physical vulnerability (Sanyal and Lu. 2006; Shanon et al., 1994; Visser et. al 2012; Weber et al. 2015; Morrow, 1999), but very few studies have been conducted to link the physical vulnerability to the social vulnerability. Physical vulnerability could be referred to as a set of physical conditions or phenomena, such as geology, topography, climate, land use and land cover etc. which renders a place and the people living there susceptible to disaster. The degree of danger or threat and the levels of exposure and resilience to threat are closely associated with location. Hence, spatial vulnerability is a function of location, exposure to hazards, and the physical performance of a structure, whereas socio-economic vulnerability refers to the socio-economic and political conditions in which people exposed to disaster are living. A flood hazard map integrating hydrological data with socioeconomic variables could be used to account for intangible damage (Boyle et al., 1998).

The most vital aspect shaping flood hazard is flood frequency. The Available discharge data from 1956-2014 and the inundation extent of various past flood events was collected from the state Irrigation and Flood control department, and the data was subsequently used to generate the maps showing the extent of inundation and the frequency of floods.

For working out flood vulnerability and hazard zonation, the weighting method for the hazard index was implemented in three steps. First, in order to portray the heterogeneity of dissimilar environmental and socioeconomic factors Contributing to flood hazard, all the variables were standardized and named i.e. elevation, housing density, population density, literacy, primary working population, female population, total households and total working population. Second, a knowledge-based weighting method was applied to each of the variables, 
indicators that represent a high level of diffusion were given more weight; a variable depicting a uniform situation across the study area is not likely to distinguish between hazardous and non-hazard zones.

As the study area includes both urban and rural areas, the spatial analysis unit was taken as ward and village for urban and rural areas respectively. The indicators were reclassified to a common evaluation scale (1-5) for analysis. Since the indicators contribute differently to flood vulnerability therefore based on their sensitivity, a percent influence value was assigned to each indicator. The highest value (30\%) was given to elevation because under normal conditions (without structural measures), it determines the flood impact, followed by housing density, population density and total house hold with percent influence value of $(15 \%)$ each. Total working population influences by $(10 \%)$ and indicators like population literacy, female population and population working in primary sector influences by $(5 \%)$ each.

The methodology adopted for assessing the physical and social vulnerability of the location and people is schematically shown in the Fig. 2, below. The step-wise approach followed for the assessing the flood vulnerability is discussed here under

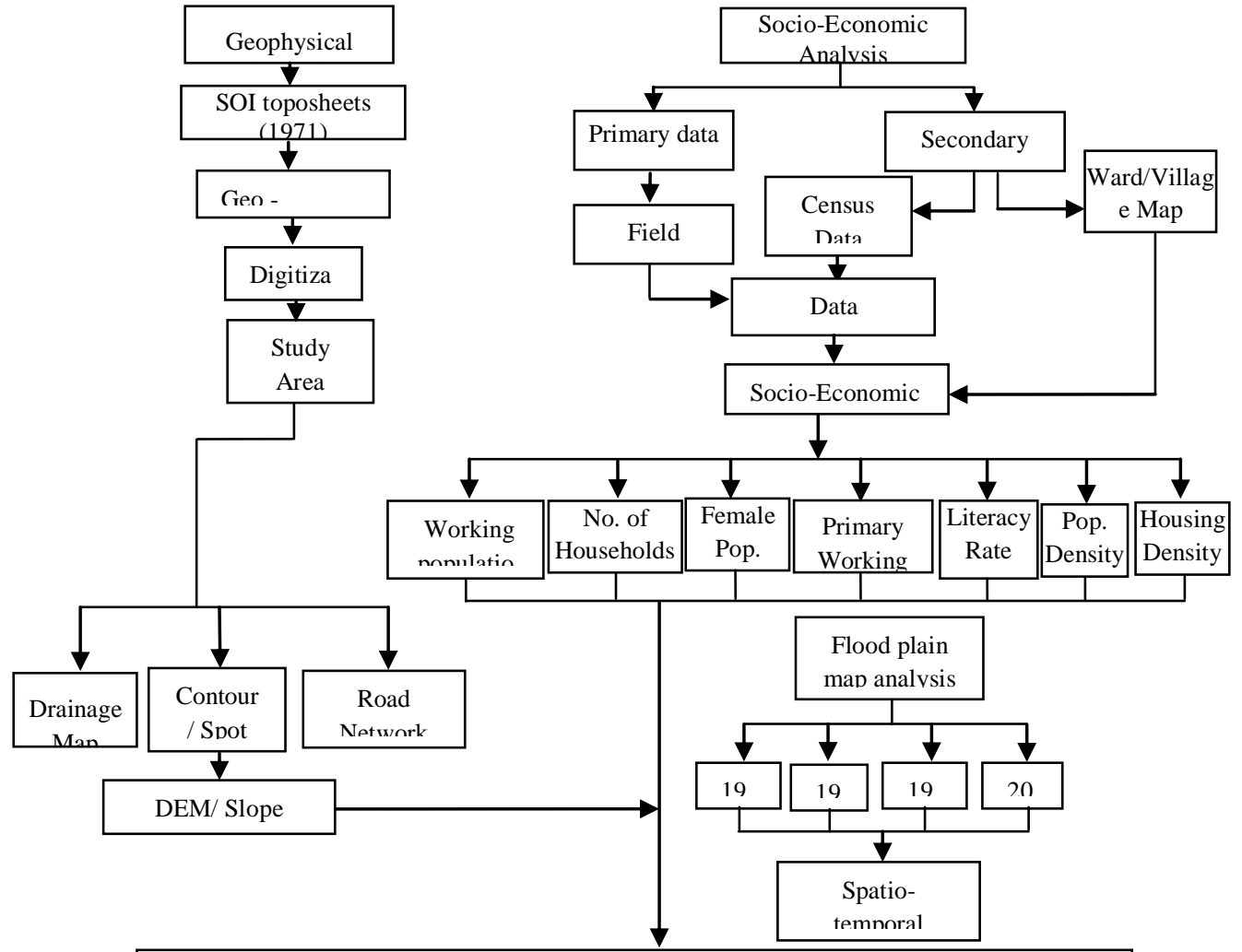

Weight Assigned to each parameter sensitive to flood as per their appropriateness

Multi criteria evaluation, weight calculation and composite calculation using Rank sum $\checkmark$

Preparation of composite index map of flood vulnerability High, Medium and Low)

$\checkmark$

Overlay of village/ward boundary layer attributed with census data on flood hazard map

Identification of vulnerable Areas under different zone of flood vulnerability/Hazard

Fig. 2 Flow Chart of the Methodology 


\section{Results and Discussion:-}

The ward and revenue village, the smallest rural/urban unit of human settlement, was selected as the most significant unit of study for vulnerability and hazard mapping. Available historical maps (Flood inundation extents) showing the annual flood affected areas for the study area were used to map the extent of floods having a specific frequency which was calculating using various statistical methods (Figure 3 ).

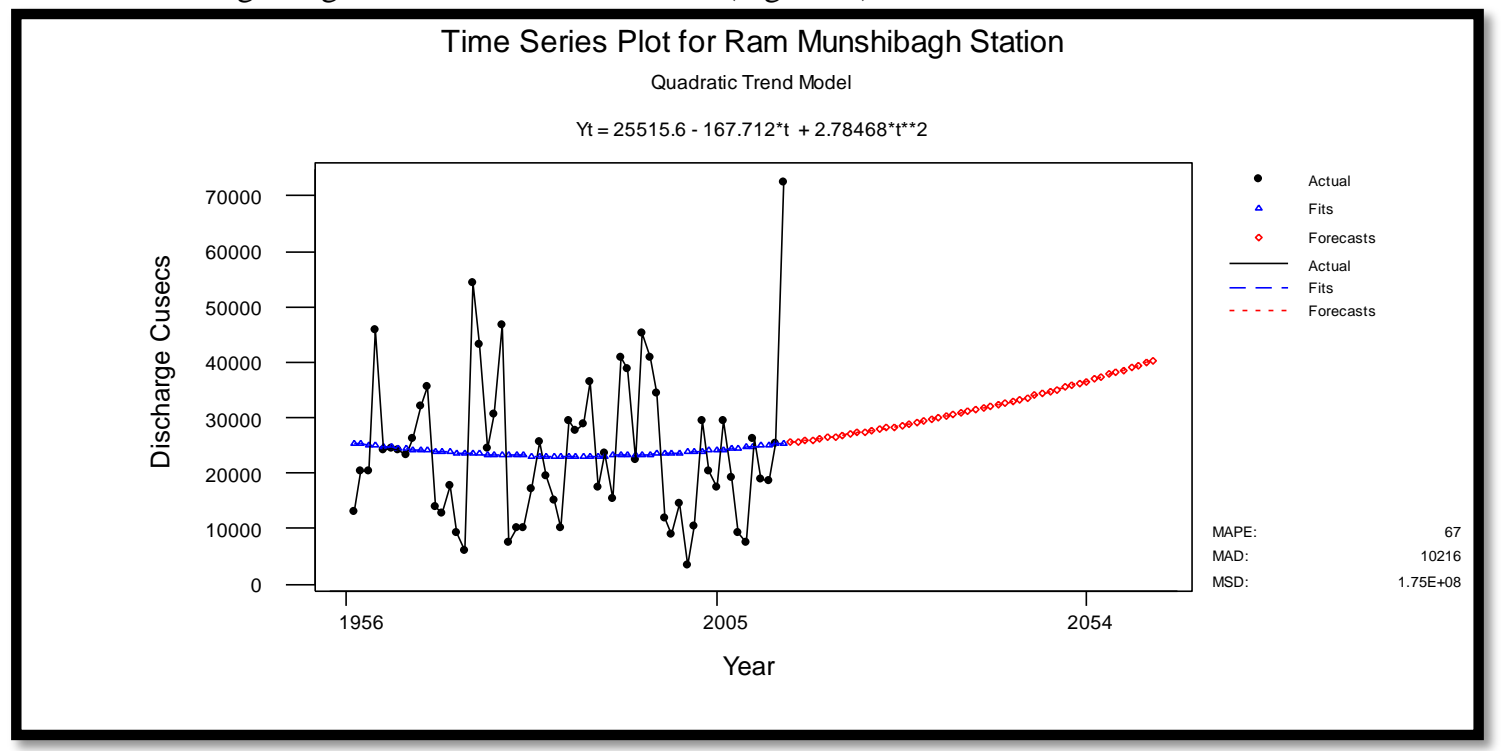

Fig 3:- Time series plot of discharge at Ram Munshi Bagh Gauging station

The inundated areas in each year were converted into individual GIS layers; flood occurrence for each revenue village/urban ward was calculated by intersecting each map with the village boundary layer .Thus flood hazard Zonation mapping of the study area has been carried out by integrating past flood inundation maps of various flood events viz-a-viz 1988, 1992, 1997 and 2006, the inundated extent of these flood events as shown in the figure 4a, and the elevation criteria obtained from the use of bench marks and spot heights from the toposheets of the study area (Figure $4 \mathrm{~b}$ ). Thus the hazard Zonation map for the study area was obtained after integrating all the map layers in GIS using overlay analysis.

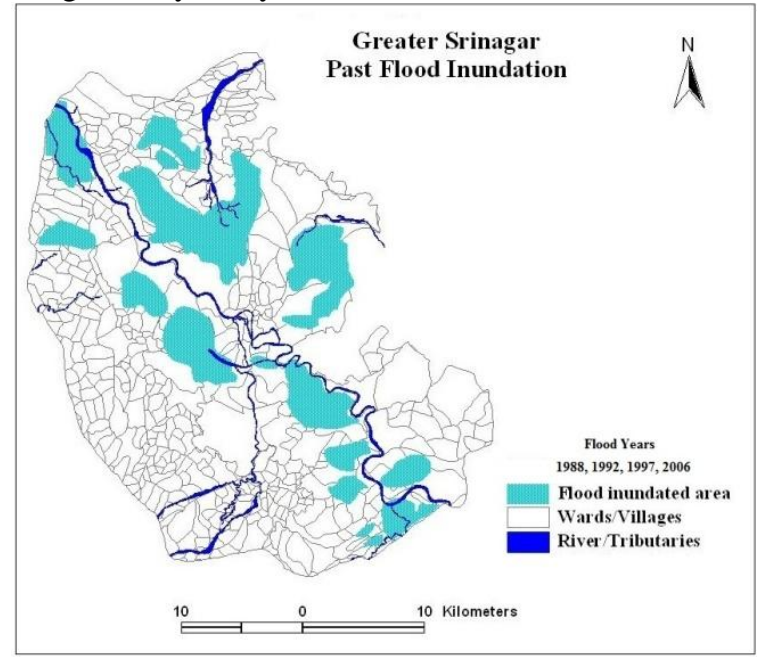

Fig. 4:- (a) Innundation extent of past floods

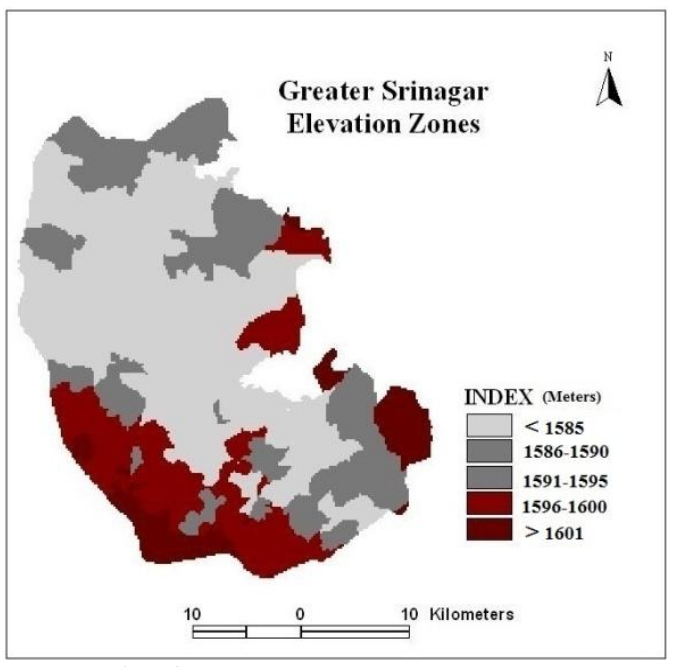

Fig. 4:- (b) Elevation Zonation Map

From all the possible combinations achieved in the overlay analysis, the study area were ultimately categorised into four flood hazard zones; high hazard zone, moderate hazard zone, low hazard zone and no flood area zone. The figure 5 below shows spatial distribution of flood hazard zones of greater Srinagar. 


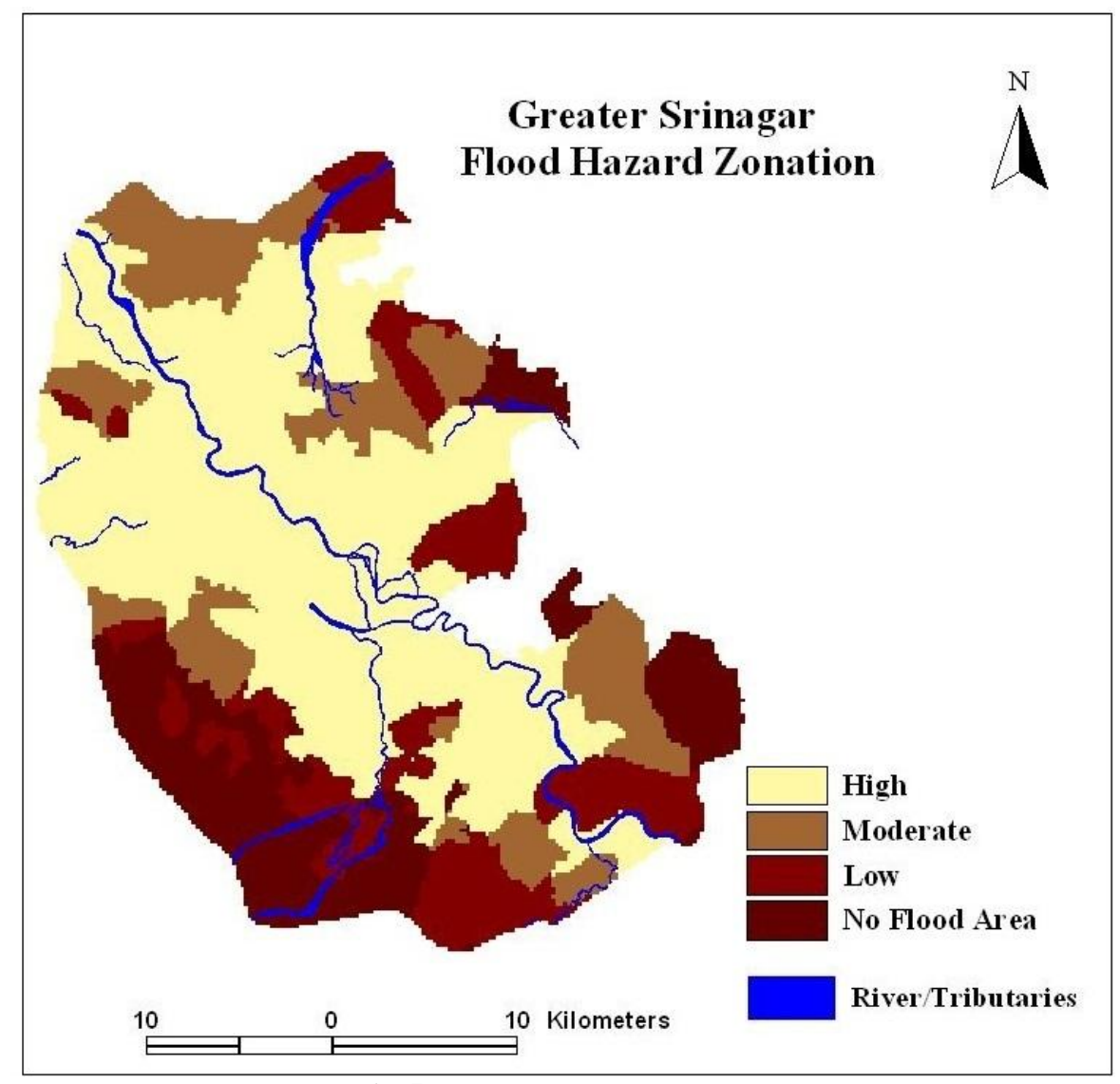

Fig 5:- Flood Hazard Zonation

The map obtained thereof reveals that greater Srinagar has an area of 505.43 sq.kms, amounting 47.29 percent of the total area of greater Srinagar in high flood hazard zone, an area of 164.61 sq.kms, amounting 15.40 percent of the total area in moderate hazard zone and an area of 242.25 sq.kms amounting 22.66 percent of area in low hazard zone. An area of $156.43 \mathrm{sq}, \mathrm{kms}$ amounting 14.64 percent of the total area of the study area is categorized in no flood area, as this zone comprises of elevated land of the study area and has never encountered the flood event and hence termed as no flood area. The high and moderate hazard zone lies below the 1600 meter altitude, which constitutes the major areas of the city and the low lying parts of the study area, which remains continuously under flood threat whenever there is continuous rain for two to three days, this area gets inundated as has been seen in the past flood events and creates miseries for the people living in these areas. The low hazard zone and no flood area lies above the 1600 meter altitude and constitutes the uplands of Harvan, Pampore and Budgam, these areas have very good connectivity with the main city and so can be developed for commercial and residential purposes so as to lower the pressure on the city, which in turn will help in reducing the flood hazard vulnerability.

Hence after generation of the flood hazard zonation map of the study area which will be usefully linked with the socio-economic variables selected for the present study for the generation of the flood vulnerability map of the study area. Thus in order to accomplish the flood vulnerability assessment, the socio-economic data analysis of the study area was carried out using various statistical and geo-spatial techniques. The socio-economic data analysis was carried out at village and ward level using the census data. The socio-economic data had to be converted into the GIS format for geospatial analysis of the various socio-economic parameters. Socio-economic GIS is a new emerging field that provides insight into the socio-economic aspects of environmental and physical problems and could be useful aid for linking the environmental problem to societies (Buckle et al., 2000). .

The whole study area comprises of 537 villages with a total population of 16.25 lac persons distributed among 256093 numbers of households. Various socio-economic parameters like total population, population density, female population, total literacy, total households, housing density ,total working population, primary working 
population and one of the main parameter that is flood hazard map shown and discussed above have been analyzed using geo-spatial technique, showing in the following figures 6(a) to figures. $6(\mathrm{~h})$

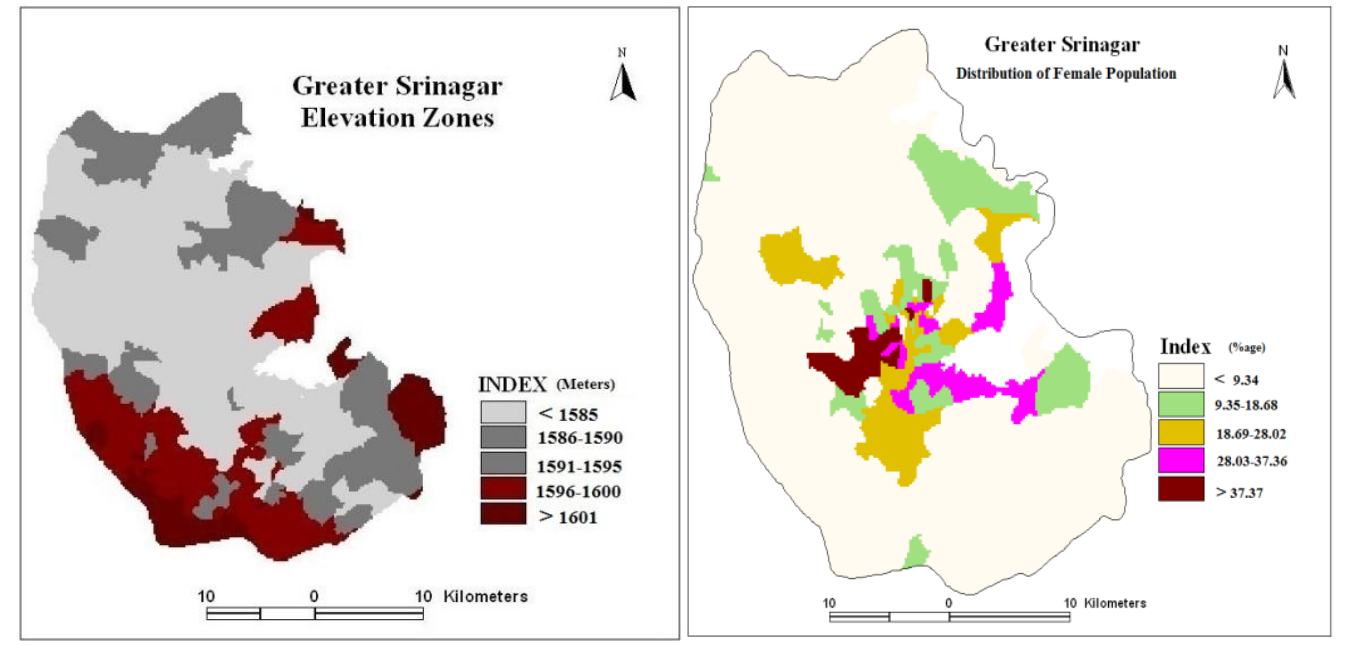

Fig. 6 (a)

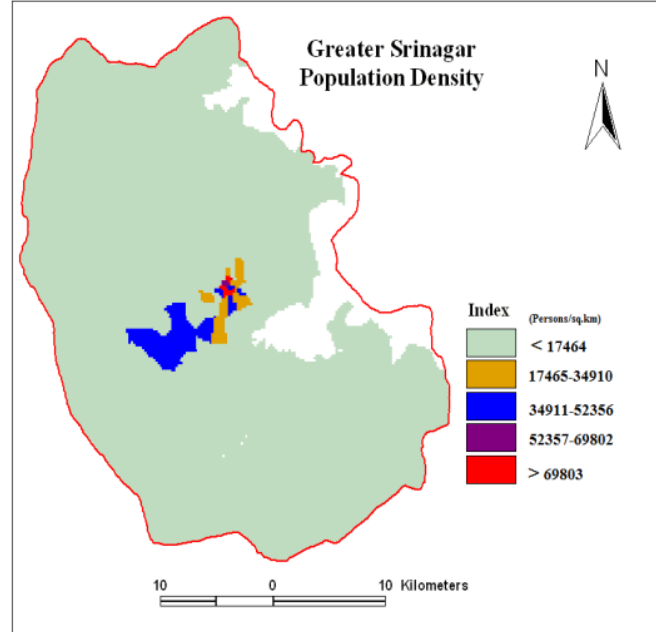

Fig. 6 (c)

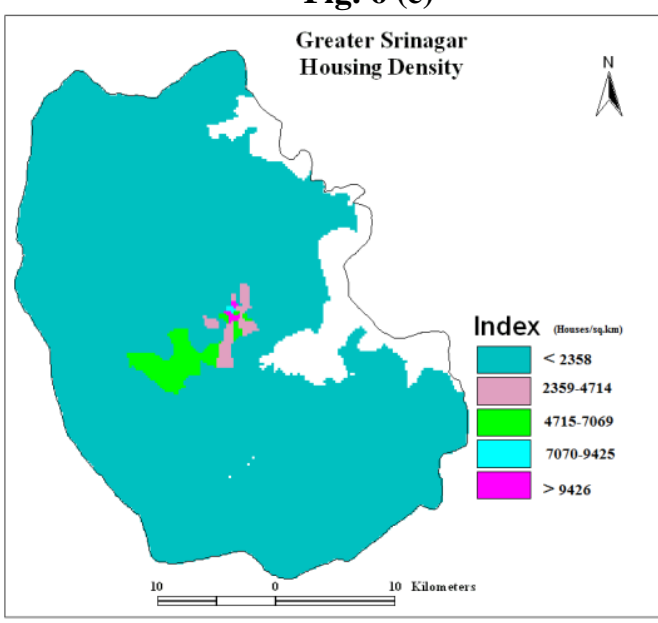

Fig. 6 (e)
Fig. 6 (b)

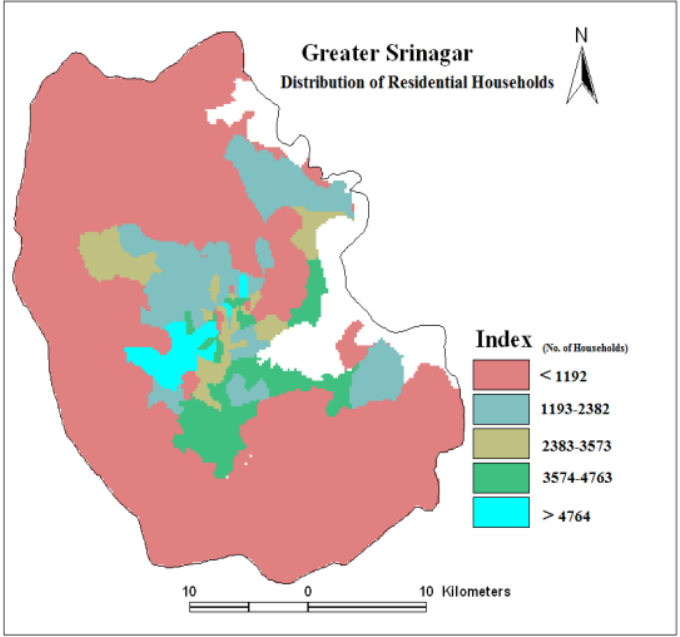

Fig. 6 (d)

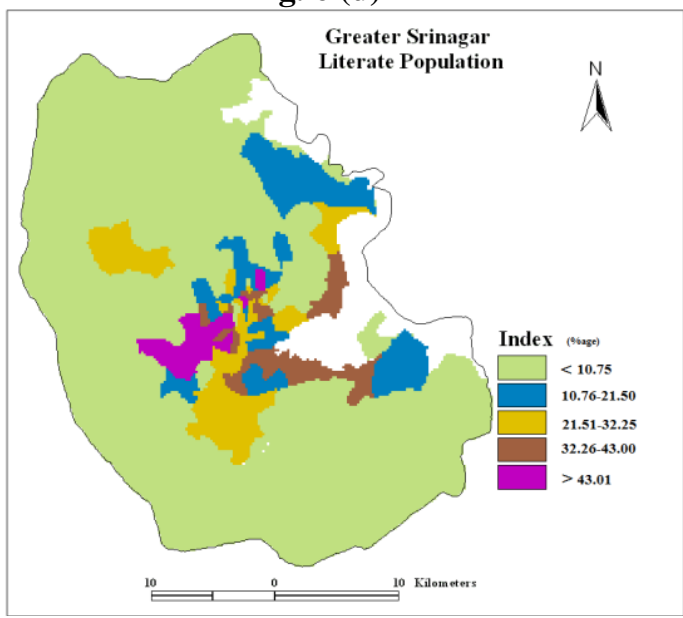

Fig. 6 (f) 


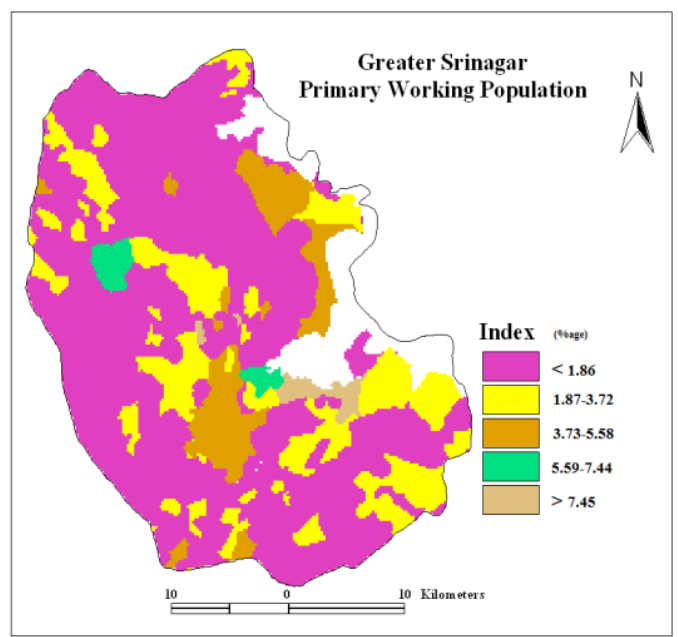

Fig. 6 (g)

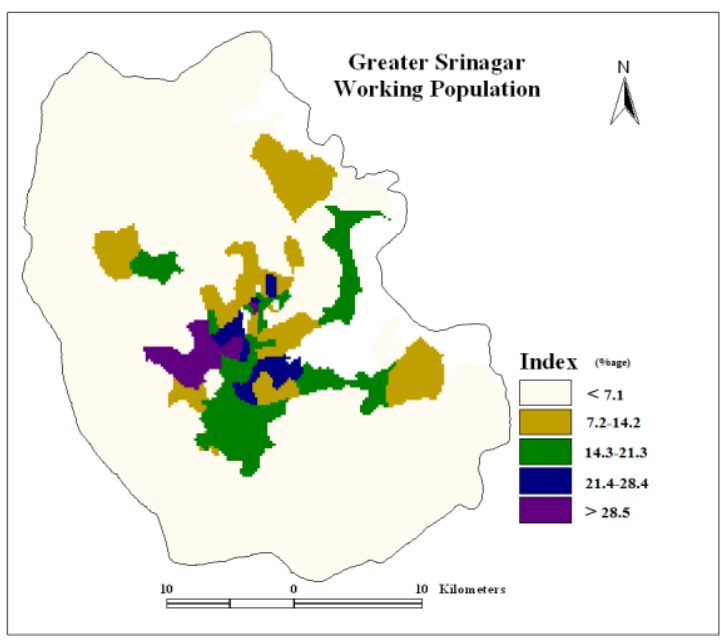

Fig. 6 (h)

Fig. 6:- (a) - 6 (h) Map Layers of Various Parameters used in the study.

The weighting scheme for the vulnerability index was implemented in three steps. First, in order to depict the heterogeneity of different environmental and socio-economic factors contributing to flood hazard, all the eight variables were standardised and named. Second a knowledge-based weighting scheme was applied to each of eight variables: indicators that represent a high level of dispersion were given more weight; a variable depicting a uniform situation across the study area is not likely to distinguish between vulnerable and non vulnerable zones. The variable 'elevation' was attached to high importance (Table 1) because the low lying areas of the study areas are frequently inundated by flood water.

Table 1;- Parameters and Weights

\begin{tabular}{|c|c|c|c|}
\hline Parameters/units & $\begin{array}{c}\text { Weightage of } \\
\text { Variables } \\
(\% \text { age })\end{array}$ & Sub-class of parameters & Rank \\
\hline \multirow{5}{*}{$\begin{array}{c}\text { Elevation } \\
\text { (Meters) }\end{array}$} & \multirow[t]{5}{*}{$30 \%$} & $<1585$ & 1 \\
\hline & & $1586-1590$ & 2 \\
\hline & & $1591-1595$ & 3 \\
\hline & & $1596-1600$ & 4 \\
\hline & & $>1600$ & 5 \\
\hline \multirow{5}{*}{$\begin{array}{l}\text { Housing Density } \\
\text { (Houses/sq.km) }\end{array}$} & \multirow[t]{5}{*}{$15 \%$} & $>9426$ & 1 \\
\hline & & $7070-9425$ & 2 \\
\hline & & $4715-7069$ & 3 \\
\hline & & $2359-4714$ & 4 \\
\hline & & $<2358$ & 5 \\
\hline \multirow{5}{*}{$\begin{array}{l}\text { Population Density } \\
\text { (Persons/sq.km) }\end{array}$} & \multirow[t]{5}{*}{$15 \%$} & $>69803$ & 1 \\
\hline & & $52357-69802$ & 2 \\
\hline & & $34911-52356$ & 3 \\
\hline & & $17465-34910$ & 4 \\
\hline & & $<17464$ & 5 \\
\hline \multirow{5}{*}{$\begin{array}{l}\text { Literate Population } \\
\text { (\%age) }\end{array}$} & \multirow[t]{5}{*}{$5 \%$} & $<10.75$ & 1 \\
\hline & & $10.71-21.50$ & 2 \\
\hline & & $21.51-32.25$ & 3 \\
\hline & & $32.26-43.00$ & 4 \\
\hline & & $>43.01$ & 5 \\
\hline \multirow{4}{*}{$\begin{array}{c}\text { Primary Working Population } \\
\text { (\%age) }\end{array}$} & \multirow[t]{4}{*}{$5 \%$} & $>7.45$ & 1 \\
\hline & & $5.59-7.44$ & 2 \\
\hline & & $3.73-5.58$ & 3 \\
\hline & & $1.87-3.72$ & 4 \\
\hline
\end{tabular}




\begin{tabular}{|c|c|c|c|}
\hline & & $<1.86$ & 5 \\
\hline \multirow{5}{*}{$\begin{array}{l}\text { Females Population } \\
\text { (\%age) }\end{array}$} & \multirow[t]{5}{*}{$5 \%$} & $>37.37$ & 1 \\
\hline & & $28.03-37.36$ & 2 \\
\hline & & $18.69-28.02$ & 3 \\
\hline & & $9.35-18.68$ & 4 \\
\hline & & $<9.34$ & 5 \\
\hline \multirow{5}{*}{$\begin{array}{c}\text { Households } \\
\text { (No. of Houses) }\end{array}$} & \multirow[t]{5}{*}{$15 \%$} & $>4764$ & 1 \\
\hline & & $3574-4763$ & 2 \\
\hline & & $2383-3573$ & 3 \\
\hline & & $\begin{array}{l}193-2382 \\
\end{array}$ & 4 \\
\hline & & $<1192$ & 5 \\
\hline \multirow{5}{*}{$\begin{array}{ll}\text { Working } & \\
& \text { (\%age) }\end{array}$} & \multirow[t]{5}{*}{$10 \%$} & $<7.1$ & 1 \\
\hline & & $7.2-14.2$ & 2 \\
\hline & & $14.3-21.3$ & 3 \\
\hline & & $21.4-28.4$ & 4 \\
\hline & & $28.5-35.5$ & 5 \\
\hline
\end{tabular}

Villages were ranked for each of the indicators. Vulnerable ranks are commonly integrated into multiplicative model to create a composite vulnerability index. A knowledge based ranking procedure was adapted to effectively use all the vulnerability indicators in a composite framework. The main objective of the analysis was to obtain a general identification of the critical areas which are frequently affected by floods and hence are more vulnerable and at the same time identification of the less and moderately vulnerable areas of the study area, which will be helpful for the future develop, thus after performing the multi-criteria overlay analysis approach for the said indicators in GIS environment, three classes of vulnerability viz-a-viz Low, Moderate and High vulnerability classes were generated as depicted in the fig. 7 and class wise statistics of every zone were computed which is depicted in the table 1.2.

Fig 7:- Classified Maps of Settlements Vulnerable to Flood

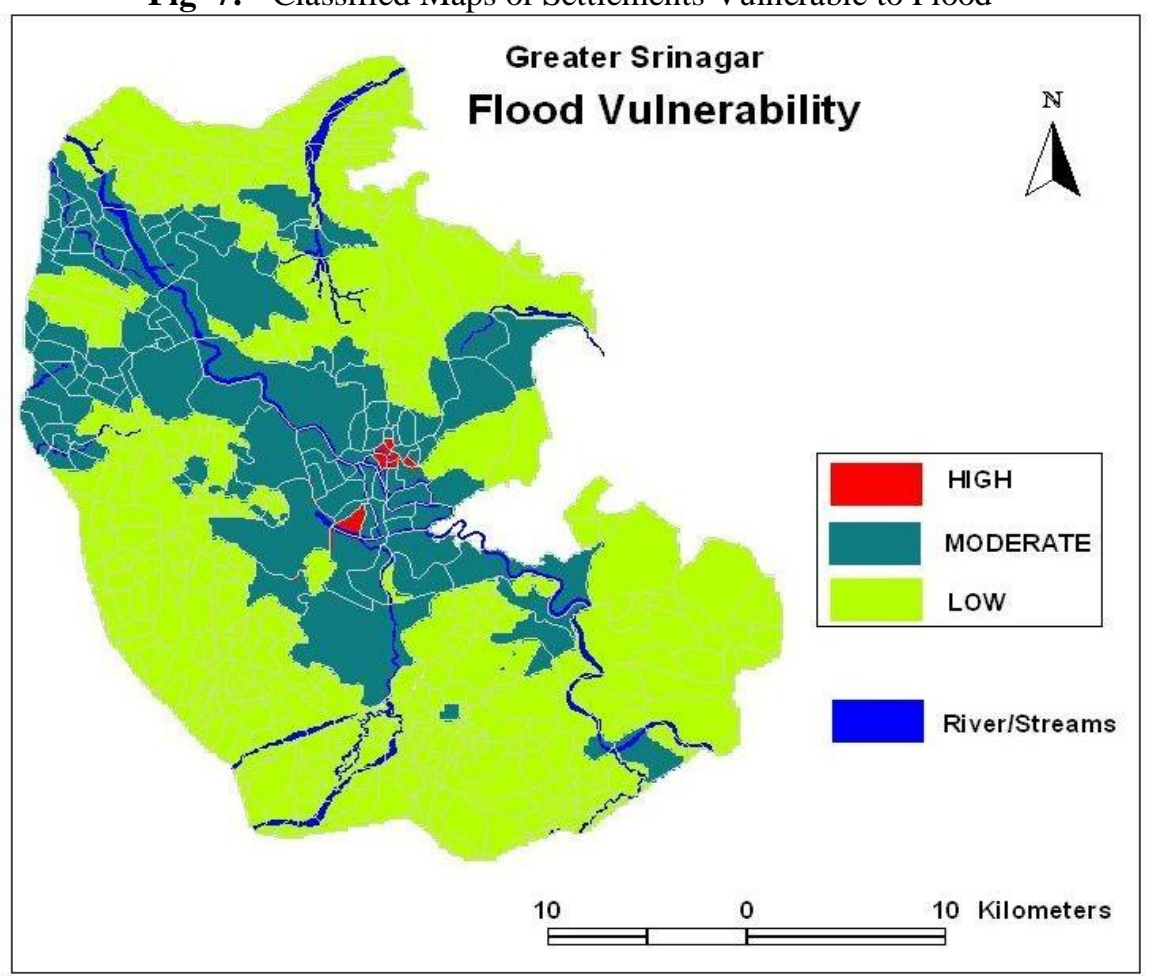

Source: Generated from Census of India 2001 and 2011 
Table 1.2:- Flood hazard Vulnerability

\begin{tabular}{|c|c|c|c|c|c|c|}
\hline Sr. No & $\begin{array}{c}\text { Vulnerability } \\
\text { Class }\end{array}$ & $\begin{array}{c}\text { No. of Villages } \\
\text { likely to be } \\
\text { Affected }\end{array}$ & $\begin{array}{c}\text { Total } \\
\text { Population } \\
\text { Likely to be } \\
\text { Affected } \\
\text { (Persons) }\end{array}$ & $\begin{array}{c}\text { Per cent of } \\
\text { Total } \\
\text { Population }\end{array}$ & $\begin{array}{c}\text { Number of } \\
\text { Female } \\
\text { Population } \\
\text { Likely to be } \\
\text { Affected }\end{array}$ & $\begin{array}{c}\text { No. of } \\
\text { Households } \\
\text { Likely to be } \\
\text { Affected }\end{array}$ \\
\hline 1 & Low & 424 & 620662 & 39 & 298001 & 90082 \\
\hline 2 & Moderate & 99 & 671212 & 41 & 309395 & 110060 \\
\hline 3 & High & 14 & 332913 & 20 & 152072 & 55951 \\
\hline & Total & 537 & 1624787 & 100 & 759468 & 256093 \\
\hline
\end{tabular}

Thus the perusal of the table reveals that 39 per cent population residing in 424 villages with 90082 households covering an area of 64.97 per cent of study area are vulnerable to low levels of flood, while as 41 per cent population belonging to 99 villages with 110060 households covering area of $34.66 \%$ out of the total area of the greater Srinagar vulnerable to moderate floods. However about 20 per cent population of 14 villages with 55952 households covering an area of only $0.35 \%$ are highly vulnerable to floods. The names of the villages and wards falling in the high and moderate hazard zones are shown in the fig. 7(a) and 7(b)

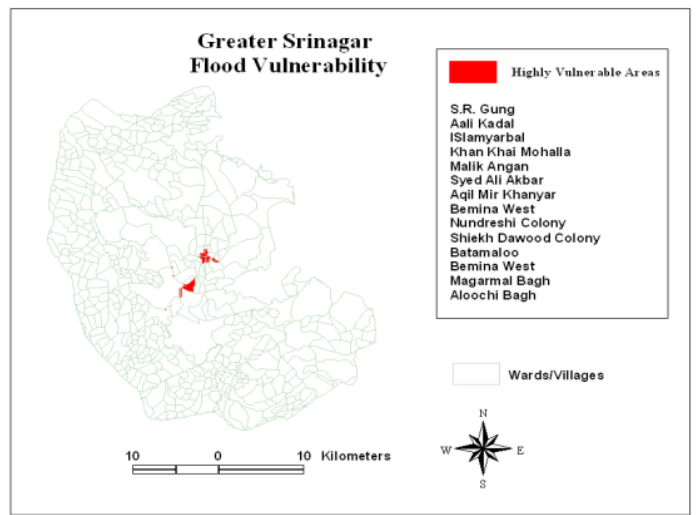

Fig. 7:- (a) High Vulnerable Villages

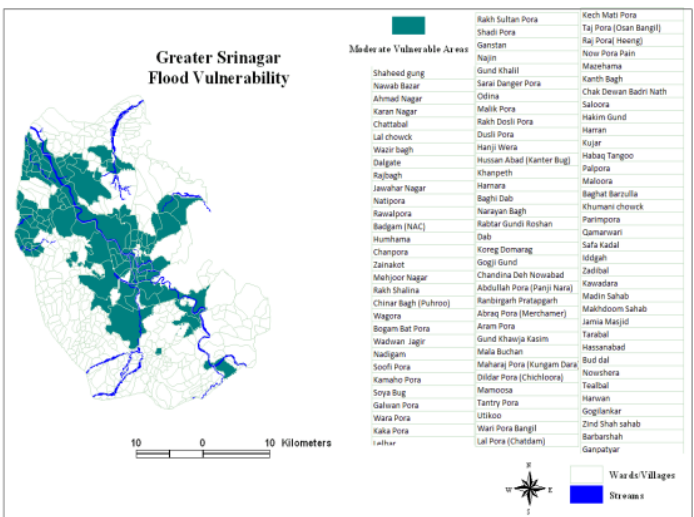

Fig. 7:- (b) Moderate vulnerable villages

\section{Flood Hazard Zonation:-}

\section{Conclusion:-}

GIS mapping provide improved ways of presenting vulnerability and hazard risk that can be applied at local levels. The flood vulnerability analysis and mapping helps to planner, insurers and emergency services. It is a valuable tool for assessing flood risk and preparedness to mitigate the impact of flood. The study fully appraised the role of Geo informatics in decision making process using GIS based flood hazard zoning maps.

The study shows that 39 per cent population residing in 424 villages with 90082 households covering area of $64.97 \%$ of study area vulnerable to low, 41 per cent population belonging to 99 villages with 110060 households covering area of $34.66 \%$ out of the total area of the study area vulnerable to moderate and about 20 per cent population of 14 villages with 55952 households covering an area of only $0.35 \%$ are highly vulnerable to flood hazard.

This Study also shows that greater Srinagar has an area of 505.43 sq.kms, amounting 47.29 percent of the total area of greater Srinagar in high flood hazard zone, an area of 164.61 sq.kms, amounting 15.40 percent of the total area in moderate hazard zone and an area of 242.25 sq.kms amounting 22.66 percent of area in low hazard zone. An area of $156.43 \mathrm{sq}, \mathrm{kms}$ amounting 14.64 percent of the total area of the study area is categorized in no flood area, as this zone comprises of elevated land of the study area and has never encountered the flood event and hence termed as no flood area.

The study also helped in determining the overall vulnerability of the people and places in the study area which shall aid in developing and designing developmental schemes that aim at enhancing the social status of the people living 
in these villages and wards and also taking up physical flood control measures to reduce the vulnerability of the people living in the greater Srinagar. Particularly the hazard Zonation shall facilitate development of zonal and targeted plans in the study area to develop robust strategy for mitigation and control of floods in the long run.

\section{References:-}

1. Adger W. N. and Kelly P. M. (1999). Social vulnerability to climate change and the architecture of entitlements. Mitigation and Adaptation Strategies for Global Change 4: 253-266, Kluwer Academic Publishers, Netherlands.

2. Barroca B., Bernardara P., Mouchel J. M., and Hubert G. (2006). Indicators for identification of urban flooding vulnerability. Nat. Hazards Earth Syst. Sci., 6, 553-561.

3. Bhat M S. (2008) Urban System in Himalayas -A case study of Srinagar city -region, Ariana Publishers and Distributors, New Delhi.

4. Bhat M. S. Alam A. (2014) Tracking the reasons: strong monsoon currents triggering multiple cloud bursts caused the catastrophe. http://www.greaterkashmir.com/news/gk-magazine/tracking-the-reasons/179066.html

5. Birkmann J. (2006). Measuring vulnerability to natural hazards: Towards disaster resilient societies, United Nations University.

6. Birkmann J. (2006). Measuring vulnerability to promote disaster-resilient societies: Conceptual frameworks and definitions. PMU: WSL (W) 15/8/06 pp. 7-54 1589_01 (p. 9).

7. Boyle SJ, Tsams IK, Manber ASCE et al. (1998) Developing geographical information system for land use assessment in flood conditions. Journal of Water Resource Planning and Management 124, 89- 98.

8. Buckle P. Mars, G et al. (2000). New Approaches to Assessing n Vulnerability and Resilience, The Australian Journal of Emergency Management, Vol. 15, No. 2, pp.8-15.

9. Burton C, Cutter S.L.2008. Levee failures and social vulnerability in the Sacramento - San Joaquin Delta area, California. Natural hazards review 9(3). Pp. 136-

10. Cançado V., Brasil L., Nascimento N., Guerra A. (2008). Flood risk assessment in an urban area: Measuring hazard and vulnerability. 11th International Conference on Urban Drainage, Edinburgh, Scotland, UK.

11. Census of India (2011). District census handbook, - SRINAGAR-SERIES-02 , PART XII-B -Jammu and Kashmir.

12. Cutter S. L. and Finch C. (2008).Temporal and spatial changes in social vulnerability to natural hazards PNAS, 105, 7, 2301-2306, doi: 10.1073/pnas.0710375105.

13. Cutter S, L Boruff B J Shirley W.L (2003) Social Vulnerability to environmental hazards. Social science Quarterly 84(2), pp. 242-261.

14. Cutter S. L., Boruff B. J., Shirley, W.L. (2003). Social vulnerability to environmental hazards. Social Science Quarterly 84, 242-261.

15. Eakin H, Luers A.L. (2006). Assessing the vulnerability of social environmental systems. Annual review of environmental and Resources 31, pp.365-394.

16. Fekete A. , Damm M., Birkmann J. (2009). Scales as a challenge for vulnerability assessment. Nat Hazards (2010) 55:729-747, DOI 10.1007/s11069-009-9445-5.

17. Ghosh G.K (2006). Disastr Management A.P.H publishing corporation, New Delhi. Vo.1 pp. 321-324.

18. Goodyear R. K., Fabian A. and Hay J. (2011). Finding the crowding index that works best for New Zealand (Statistics New Zealand Working Paper No 11-04). Wellington: Statistics New Zealand.

19. Kienberger S. (2007) Assessing the vulnerability to natural hazards on the provincial/community level in Mozambique: the contribution of GIscience and remote sensing, Joint CIG/ISPRS conference on geomatics for disaster and risk management, Toronto, Canada.

20. Koul P. A. (1991) Geography of Jammu and Kashmir State, Verinag Publishers.

21. Koul, A. (1978). Geography of Jammu And Kashmir State. Light and Life Publishers. University of Michigan.

22. Koul, P.A., 1993. Geography of Jammu and Kashmir state ,Thacker spink, Calcutta, India.

23. Morrow B. H. (1999). Identifying and Mapping Community Vulnerability. Disasters, 23(1):1-18

24. Raza, M., Ahmad, A., Mohammad, A., 1978. The Valley of Kashmir: A Geographical Interpretation, Vol. 1: The Land. Vikas, New Delhi.

25. Sanyal J. and Lu X.X. (2006). GIS-based flood hazard mapping at different administrative scales: A case study in Gangetic West Bengal, India. Singapore Journal of Tropical Geography 27, $207-220$,doi:10.1111/j.14679493.2006.00254.x

26. Shannon M. P., Lonigan C. J., Finch A. J., Jr. and Taylor C.M. (1994) Children Exposed to a Disaster: Epidemiology of Post-Traumatic Symptom Profiles. Journal of the American Academy of Child and Adolescent Psychiatry 33(1): 80-93. 
27. Tapsell, S., McCarthy S., Faulkner H., \& Alexander M. (2010): Social Vulnerability and Natural Hazards. CapHaz-Net WP4 Report, Flood Hazard Research Centre - FHRC, Middlesex University, London (available at: http://caphaz-net.org/outcomes-results/CapHaz-)

28. Turner B. L., Kasperson R. E., Matson P. A., McCarthy J. J., Corell R. W., Christensen L., Eckley N., Kasperson J. X., Luers A., Martello M. L., Polsky C., Pulsipher A, and Schiller A. (2003). A framework for vulnerability analysis in sustainability science. PNAS 100.14 _ 8077, doi_10.1073_pnas.1231335100

29. UNEP (2002), Assessing Human Vulnerability due to Environmental Change: Concepts, Issues, Methods and Case Studies.

30. Visser H., Bouwman A., Petersen A., and Ligtvoet W. (2012). Weather-Related Disasters: Past, Present and Future (Bilthoven: PBL Netherlands Environmental Assessment Agency) (available online at www.pbl.nl/en/publications/2012/ weather-related-disasters-past-present-

31. WCD (2000). Dams and Development: A New Framework for Decision- Making. London: Earthscan

32. Weber S., Sadoff N., Zell E. Sherbinin A. De. (2015). Policy-relevant indicators for mapping the vulnerability of urban populations to extreme heat events: A case study of Philadelphia. Applied Geography, 63, 231-241, doi:10.1016/j.apgeog.2015.07.006.

33. Wolman MG (1971) Evaluating alternative techniques of floodplain mapping. Water Resources Researches 7: $1383-1392$. 